\title{
The promise and perils of alternative market-based finance: the case of P2P lending in the UK
}

\author{
Vincenzo Bavoso ${ }^{1}$
}

Published online: 16 November 2019

(c) The Author(s) 2019

\begin{abstract}
The collapse of the global financial industry in 2008 and the subsequent decay of most Western economies into a period of prolonged economic stagnation have represented a springboard for the progressive growth of alternative channels of financial intermediation. The reluctance and inability of mainstream banks in the post-crisis years to provide credit facilities to the real economy, most critically to start-ups and small and medium-sized enterprises, propelled the latest wave of financial innovation, this time under the guise of FinTech. Much has been written on the rise of FinTech in recent years, but there is still insufficient clarity about the benefits that this phenomenon is bringing to the real economy and the potential risks that can arise from its growth. This paper maps the development of FinTech lending platforms in the UK and reconceptualises the rationale for their growth. In doing that, this study focuses on the structure and operation of the main UK platforms, recognising that while some are effectively banks that adopt a technology-based business model, many platforms operate under the P2P business model. The question then is to assess the policy and regulatory approach that is relevant to UK P2P platforms. Interestingly, the emergence of $\mathrm{P} 2 \mathrm{P}$ securitisation raises a number of regulatory and policy questions, because longer intermediation chains typical of securitisation may well defy the social and economic purposes under which the idea of P2P developed. Furthermore, questions of systemic risk inevitably resurface in these types of transactions. Ensuing problems related to the best way to regulate these new channels of financial intermediation lead to critically evaluate the initiatives launched by the UK FCA, initially under the Innovation Hub, and more recently under the consultation for a new regulatory framework.
\end{abstract}

Keywords P2P lending $\cdot$ FinTech $\cdot$ Financial intermediation $\cdot$ Market-based finance $\cdot$ P2P securitisation $\cdot$ Financial conduct authority $\cdot$ Credit risk $\cdot$ Systemic risk

Only in the financial world is there such an efficient design for concealing what, with the passage of time, will be revealed as selfand general delusion J. K. Galbraith ${ }^{1}$

I am grateful for insightful comments received during a seminar hosted on 15 January 2019 by the Centre for Banking and Finance Law, Faculty of Law, National University of Singapore. I also thank the reviewers for their constructive comments.

Vincenzo Bavoso

vincenzo.bavoso@manchester.ac.uk

1 University of Manchester, Manchester, UK

\section{Introduction}

This article takes a step back from the hype ${ }^{2}$ associated with the recent boom of FinTech in the UK. It does so by reflecting on the trajectory of this process and its likely consequences in the short and medium term. In particular, this article is focused on questioning the nature of the FinTech phenomenon in relation to the channels of financial intermediation that it elicits. It then addresses the question enshrined in the above quote by J. K. Galbraith, of whether this is

\footnotetext{
1 Galbraith [35].

${ }^{2}$ Interestingly, a recent paper by the Basel Committee has referred to the "Hype Cycle", identifying five characterising moments in it, namely (1) the innovation trigger, (2) the peak of inflated expectations, (3) trough of disillusionment, (4) slope of enlightenment and (5) plateau of productivity. See BCBS [12].
} 
simply another wave of financial innovation, which like the most recent ones will result in a speculative fever and in instability, or whether it can provide some long-term benefits to the real economy.

In order to address these issues, this article focuses on the recent growth of the FinTech industry in the UK, and specifically on the most common form of FinTech intermediation, which takes place on P2P (peer-to-peer) lending platforms. ${ }^{3}$ While the UK is currently the third P2P market in the world behind the USA and China, ${ }^{4}$ its experience provides some useful directions, especially with respect to the regulatory approach towards alternative finance. The UK Financial Conduct Authority (FCA) has recently emphasised the importance of promoting market-based forms of financial intermediation in order to alleviate the burden traditionally borne by commercial banks. ${ }^{5}$ Moreover, emphasis has been laid on encouraging innovative, tech-based firms that provide alternative financial services, disrupting the more traditional banking business on the one hand, and providing benefits for consumers on the other. ${ }^{6}$

P2P platforms epitomise the idea of disintermediated "middle-man-free" access to finance, especially insofar as platforms are conceived as technological means that allow borrowers to directly access available funding on the one hand, and lenders to invest in specific loans on the other. The idea, in other words, is to facilitate access to finance at cheaper rates, especially for retail consumers and small and medium-sized enterprises, because of the reduced operational and intermediation costs of $\mathrm{P} 2 \mathrm{P}$ platforms (typically, the function of intermediating finance is associated with banks). Under this model, lenders too benefit from higher rates of return than they would receive on conventional financing channels.

Importantly for the purpose of this study, the FCA's stance initially revolved around a more facilitative regulatory approach for FinTech firms, which would not be burdened by the same regulatory constraints that are normally associated with financial institutions. While the rationale behind this stance is commendable, ${ }^{7}$ it has already raised a number of regulatory and policy issues. Firstly, it has exposed problems of consumer protection, which were recently exemplified by the collapse of a small Manchester-based P2P platform. ${ }^{8}$ As

\footnotetext{
3 These are also commonly referred to in the literature as loan-based crowdfunding platforms. See for instance Havrylchyk [41].

4 See Claessens et al. [17].

5 Aquilina and Kraus [1].

${ }^{6}$ See FCA Innovation Hub (website) [28].

7 The rationale is that if small tech-based platforms were to be burdened by regulatory constraints, as other financial firms are, they would not be able to operate and survive. See Starks [54].

${ }^{8}$ Beioley [13].
}

this platform entered administration, it emerged that it had operated for a period without the necessary FCA authorisation. Its investors (the lenders) therefore were not afforded the same degree of protection that is normally due to investors of entities that are authorised and regulated by the FCA. ${ }^{9}$ In this particular case, investors were also affected by the platform's difficulty to refinance a number of highrisk loans, and by the increase in the number of defaults. ${ }^{10}$

Secondly, at a higher policy level, a relaxed approach to the regulation of FinTech generally, and P2P specifically, may raise systemic risks concerns. While these have so far been downplayed due to the limited size at present of the UK P2P market, ${ }^{11}$ the modus operandi of most platforms shows strong elements of interconnectedness with the mainstream financial system. As will be explained later in this article, P2P platforms have increasingly resorted to institutional investors in order to match borrowers' demands, and the practice of securitising $\mathrm{P} 2 \mathrm{P}$ loans has also become common. In April 2016, one of the leading P2P platforms, Funding Circle, was reported as having launched its first securitisation programme. ${ }^{12}$ While the process of securitisation will be explained later in this article, the application of securitisation adds in itself an element of complexity to $\mathrm{P} 2 \mathrm{P}$ channels of intermediation, which were instead intended to provide a streamlined and more direct access to finance. It will be contended in this article that securitisation raises questions of interconnectedness and systemic risk, which were also highlighted by the Financial Stability Board (FSB) in $2017 .{ }^{13}$

In order to address the above questions, this article proceeds as follows: "Reconceptualising FinTech, P2P lending and financial intermediation" section provides a much needed reconceptualisation of the role of $\mathrm{P} 2 \mathrm{P}$ platforms in the context of financial intermediation, which in turn clarifies their character as alternative channels of finance. The structure of the UK P2P market and the main operational trends emerging in it are analysed in "The UK P2P market" section, where emphasis is laid on the possible risks flowing from this segment of the financial industry. "Regulatory challenges: addressing questions of credit risk, interconnectedness and systemic risk" section moves the debate on to the critical question of appraising the regulatory framework in

\footnotetext{
${ }^{9}$ Ibid.

${ }^{10}$ Ibid. Following this event, the FCA sought to acquire more information about the loan defaults and the way in which platforms match lenders and borrowers. This point will be further illustrated later in this article. See on this also Noonan [49].

${ }^{11}$ See Carney [16].

12 Hale [39].

${ }^{13}$ FSB and the Committee on the Global Financial System (CGFS) [32]. The FSB stressed here that the small size of the industry in the UK would not pose systemic stability risks. See also FSB [30].
} 
the UK against the risks-specifically credit risk and systemic stability - that arise in connection with P2P finance. "Concluding remarks" section concludes.

\section{Reconceptualising FinTech, P2P lending and financial intermediation}

The abbreviation FinTech (a contraction of the words "financial" and "technology"14) is becoming increasingly prominent in the legal and financial literature. Beyond the more recent hype surrounding this phenomenon, the synergy between these two spheres of knowledge is not new and has kept growing since the inception of the automated teller machine (ATM) in 1969. Subsequent advancements in information technology (IT) facilitated the development and innovation of financial markets, as we know them today. By way of examples, digitalised ledgers in the 1960s and 1970s contributed to integrate financial institutions at a global level because they represented the premise for cross-border payment, clearing and settlement functions. More recently, advancements in computer programs allowed the wide application of trading and investment techniques known as highfrequency trading (HFT) and dark pools. These represent a form of algorithmic automated trading and take advantage of high order-to-trade ratios, effectively maximising high volumes of financial data through electronic trading tools. Blockchain technology further developed the idea of digital ledgers, and it represents chronologically the last example of technology applied to financial services. ${ }^{15}$

The explosion of the global financial crisis (GFC) in 2008 unveiled a new aspect of the symbiosis between finance and technology. Until then in fact much of the innovation in FinTech had taken place within large financial institutions, which had directly benefited from the application of new technologies. As explained in a number of studies, the role and function of banks in society changed drastically in the years leading to 2008, and this contributed to a progressive shift in business models in banking. ${ }^{16}$ The general distrust towards large financial institutions after the GFC, combined

\footnotetext{
$\overline{14}$ The FSB defined FinTech as "technologically enabled financial innovations that could result in new business models, applications, processes or products...”. See Financial Stability Board (FSB) [31].

15 Blockchain is effectively a digitised, decentralised, public ledger that was initially developed as a method for the accounting of virtual currency such as bitcoin. It employs what is known as distributed ledger technology (DLT), which today has expanded to a number of commercial and financial applications. See for an overview Zheng et al. [61]

${ }^{16}$ See on the evolution of banking Buckley [15]; more specifically on the lending behaviours of banks in the pre-crisis years, see Jaffer et al. [44]
}

with their conservative lending behaviour, is widely recognised as a chief cause behind the emergence of alternative intermediation platforms. Crucially, these started to develop their own technology, which in turn facilitated cheaper "middle-man-free" access to finance. ${ }^{17}$

It has also been recently observed that the capacity of large banks to extend credit to the real economy and to support entrepreneurial activities started to be questioned in the post-crisis years. ${ }^{18}$ This assertion needs to be further understood, and specifically the mechanics of financial intermediation performed by banks need to be clarified, given that this is what has allegedly been disrupted by alternative platforms. It is widely represented in textbook examples that banks perform an intermediation function by allocating money that is deposited in their vaults to their customers as loans. ${ }^{19}$ By doing that, banks perform that allocative and intermediation function that is idealised in most treatises. ${ }^{20}$ This traditional view however has progressively become detached from the way in which commercial banks operate at present.

In a recent paper by the Bank of England, it was confirmed that commercial banks do not intermediate already existing money from savers to borrowers. Instead, they create money ex nihilo, or rather they create credit by simply extending loans to their customers, without the need of having received a certain amount of deposits. ${ }^{21}$ Thus, it is new lending that creates deposits, and not vice versa, as it was traditionally posited. ${ }^{22}$ In the UK, the only constraints that commercial banks face in this process of credit creation are represented by interest rates set by the Bank of England. Additionally though, capital requirements set by the Basel Committee $^{23}$ may make certain assets on banks' balance sheet more expensive and risk sensitive than others, thus

\footnotetext{
$\overline{17}$ See Arner et al. [5].

${ }^{18}$ See Anderson et al. [4]. It also needs to be remembered that postcrisis regulation has put banks under more pressure to set aside larger amounts of capital against risks, which meant that banks have engaged in lending to the real economy with more reluctance.

19 Under this view, the limit of the amount of lending that banks can extend would be represented by the reserve ratio. See McLeay et al. [46].

20 This view is also consistent with the idea of fractional reserve banking, whereby banks allocate a large percentage (usually 90\%) of their deposits towards the origination of loans and other assets, thereby creating new spending power, or new money (under the concept of money multiplier).

21 These new loans, created as digital entries on banks' balance sheets, are thus recorded both on the assets side (as loans) and on the liabilities side (as deposits).

${ }^{22}$ McLeay et al. [46], p. 14.

23 Through the Basel Accords. The new set of standards in this sense is represented by the Basel III framework which is operative in January 2019 and is implemented into EU law through the CRD IV (Capital Requirements Directive) package.
} 
justifying the choice of many commercial banks to invest in different asset classes than loans.

Once the intermediation role traditionally associated with commercial banks is demystified, ${ }^{24}$ it becomes easier to make sense of the disruptive role that FinTech platforms have acquired in financial services. Many P2P platforms have been promoting their role as "cost-cutters", suggesting that by eliminating the middle man (banks) they are able to offer better returns to investors and cheaper credit to borrowers. In light of the reconceptualised role of commercial banks though, it appears that rather than providing a streamlined intermediation model, FinTech and P2P platforms in particular simply aim at re-establishing an intermediation and allocative function-namely matching savers' money with entrepreneurs' lack of it-which commercial banks no longer perform. This point will be further expounded later in this article.

Economic changes in the post-crisis years and the increasing distrust towards the banking industry contributed to the emergence of an increasing number of start-up technology firms that engaged directly with the delivery of financial services and products to end-users. In most cases, the key innovation embedded in their business was represented by the technological platform engineered and employed by these firms, and that in turn facilitated the access to financial products for end-users. While the range of services offered by these technology firms can be wide, ${ }^{25}$ this article looks specifically at the business model of $\mathrm{P} 2 \mathrm{P}$ lending platforms.

The idea behind these platforms is that they represent an alternative, market-based channel of financial intermediation, allowing parties to bypass the role traditionally offered by banks, both with respect to the provision of loans and the taking of deposits. ${ }^{26}$ Alternative platforms tend in fact to attract potential lenders because of the prospect of minimising intermediation and operation costs, and therefore of better returns on their investment, in the form of interests, whereas borrowers are presented with an easier access to credit and at better terms too.

From a policy perspective, the UK FCA has been supportive of the idea of "disruptive innovation", grounded on the promotion of innovation in the interest of competition and consumers. Critically, the FCA "Project Innovate" is focused on facilitating this type of innovation by supporting firms (through the Innovation Hub) and in the process tackling regulatory barriers. ${ }^{27}$ While a critical discussion

\footnotetext{
$\overline{24}$ See on this Hockett and Omarova [42].

25 As an example, eBay has recently interrupted its arrangement with PayPal as its main payment processor, and it has started a new agreement with Dutch technology firm Adyen. See BBC [11].

${ }^{26}$ Bearing in mind that, as explained earlier in this section, the intermediation role traditionally associated with commercial banks has changed.

27 See FCA [26].
}

on the regulation of P2P platforms is reprised in "Regulatory challenges: addressing questions of credit risk, interconnectedness and systemic risk" section, the next section provides an overview of the UK market and its main business models.

\section{The UK P2P market}

\section{Policy trends and market developments}

For the purpose of this article's enquiry, it is useful to stress that the UK market so far has been characterised by the emergence of two main types of platforms, namely P2P lending and equity crowdfunding. Overall this market development fits within the more general trend that in the post-crisis years has seen more emphasis laid on market-based channels of finance. ${ }^{28}$ The same policy direction was echoed at the EU level, where the recent EU Capital Markets Union Green Paper stressed the importance to enable alternative channels of finance, with specific reference to the crowdfunding market. $^{29}$

The drive in the UK to encourage financial innovation based on new technologies was further boosted by the Financial Conduct Authority (FCA) that launched in 2014 the "Project Innovate". This aims to represent a hub for both financial and non-financial firms seeking to introduce innovative financial products and services to the market. Through the "Innovation Hub", the FCA has been trying to facilitate these firms, by directly supporting them and advising on the relevant regulatory burdens and on the process to obtain the FCA authorisation, which is necessary to conduct regulated activities. ${ }^{30}$ The Innovation Hub is also conceived as an incubator through which the FCA evaluates areas of its regulatory framework that need to be adapted in order to allow the further development of tech-based innovation. ${ }^{31}$

The above policy reflects the view of FinTech that has also been endorsed by the Financial Stability Board (FSB). The FSB defined FinTech as "technologically enabled financial innovation that should support new business models, new financial processes and products and should thus result in more competitive financial markets". ${ }^{32}$ In the UK though, there is further emphasis on the wider interest of financial

\footnotetext{
${ }^{28}$ Supra Aquilina and Kraus [1].

${ }^{29}$ See European Commission [23]. See also European Commission [24].

${ }^{30}$ See FCA [27].

${ }^{31}$ Ibid. There is an idea of disruptive innovation at the heart of the Innovation Hub, and attendant policy and regulatory tools are directed at removing unnecessary barriers.

32 Supra FSB [31].
} 
consumers, who would, according to this proposition, enjoy the benefits of easier access to finance. Among financial consumers, small and medium-sized enterprises (SMEs) tend to be at the heart of policy discourses, mainly for two reasons: firstly, because of their importance as engines of economic growth (both in the UK and even more so in continental Europe); and secondly, because post-2008 banks have not efficiently supported the activities and growth of SMEs. ${ }^{33} \mathrm{It}$ is thus believed that alternative, FinTech-based intermediation channels could represent the ideal playground for SMEs to access new sources of credit. ${ }^{34}$

Before identifying and analysing the policy and regulatory challenges that surround this emerging area of financial services, it is necessary to map the UK FinTech environment. Data from September 2017 show that there were twenty-one fully authorised platforms; sixty-six were being assessed for FCA authorisation, and thirty-two had an interim permission. It also needs to be recognised that much of the evolution of financial services conducted on FinTech platforms in the UK revolves around $\mathrm{P} 2 \mathrm{P} .{ }^{35}$ As far as the UK market is concerned, it was reported that about $14 \%$ of new lending to SMEs was provided by P2P platforms, and it was also suggested that more than half of these credits would have been unlikely to be granted by banks. ${ }^{36}$

Much of the regulatory questions related to P2P finance (explored later in this article) stem from the challenges that emerge from this particular channel of intermediation. Before appraising the regulatory framework of P2P lending, it is necessary to briefly explain the transactional dynamics of these alternative lending platforms.

Under a typical P2P agreement, a prospective borrower applies for a loan on a platform. The borrower normally has to provide credit information, which is processed and posted

\footnotetext{
33 Between 2008 and 2012 bank loans to SMEs went down from $£ 44.5$ bn to $£ 38$ bn (the amount of loans went up between 2013 and 2017). From 2012 onwards, the amount of loans originated on P2P platforms started to increase, reaching in 2017 a value of $£ 2.3 \mathrm{bn}$. See on this UK Finance [57]. From a different perspective, it was suggested in 2017 that between 55 and $60 \%$ of borrowers on P2P platforms were denied, or would have been denied, a loan from a bank. See Carney [16]. See also statistics on bank support to SMEs provided by the British Bankers Association at https://www.bba.org.uk/ news/statistics/sme-statistics/.

34 Supra Acquilina and Kraus [1]; and European Commission [23]. At the heart of the idea to promote market-based financing channels, there is the belief that banks would become more resilient as they would be able to free up regulatory capital and thus lower their costs. This would in turn lead to a more stable financial system according to this proposition.

${ }^{35}$ FSB and the Committee on the Global Financial System (CGFS) [32].

${ }^{36}$ Supra Carney [16]. In 2015, total loans originated by peer-to-peer lenders were $\$ 117$ billion in China, $\$ 40$ billion in the USA, $£ 4.5$ billion in the UK and $€ 1.1$ billion across Europe. At least in the UK, there are signs that the rate of growth for new lending has slowed recently, down from 100 to $30 \%$.
}

on the platform after it has been verified and approved by the platform itself. ${ }^{37}$ Creditors (or rather investors) at the other end of the platform can choose from the available loans those that suit their appetite for risk and return. The level of risk of each investment is effectively determined by a) the information provided by the prospective borrower, and b) the credit risk assessment provided by the platform. ${ }^{38}$

A loan contract is then entered between the borrower and the creditor, without the platform being a party to this agreement. The platform instead earns its revenue from fees related to the setting-up of the account, from the origination of the loan and its repayment. Even though platforms perform some form of credit risk assessment as explained earlier, the credit risk is not held by the platform, but by the lender. $^{39}$

These lending channels are in other words centred on websites where borrowers can solicit funds from investors. Platforms therefore operate essentially as brokers between lenders and borrowers, whereby funds are in most cases allocated to a borrower from a number of lenders. This entails that each loan includes a number of loan agreements between the borrowers and each lender, effectively a type of loan syndication.

While platforms chiefly make profits by charging fees at origination, they also operate a secondary market whereby loans can be traded before their maturity. It is important to stress that a secondary market for P2P loans is an essential feature of the market, given that the underlying loan's credit risk is left with the lender and the broker/platform does not backstop the transaction. ${ }^{40}$ Typically, in the secondary market investors are allowed to withdraw their funds if other lenders are willing to purchase the related loans. ${ }^{41}$

One predominant model across many $\mathrm{P} 2 \mathrm{P}$ platforms is that of invoice financing. Typically, businesses employ invoice financing to manage their cash flow, and sell their trade receivables (the invoices) to a third party that in turn provides them with immediate liquidity, at a discount. Platforms in this sense have started creating a secondary market for start-ups and SME loans, by either offering recourse factoring, or also by securitising their underlying loans. ${ }^{42}$

\footnotetext{
37 This process of verification and approval showcases in principle the technological advantage of these platforms vis-à-vis other forms of intermediation.

38 See Giudici [36].

39 See World Economic Forum [59].

${ }^{40}$ Ibid. Despite performing other types of intermediary services, such as enforcing lender requirements, and managing the repayment of the loan.

41 Ibid, p. 15.

42 This practice is more consolidated in the USA and in its infancy in the UK. See on this Craughan et al. [19].
} 
The necessity to facilitate a secondary market needs to be understood also in connection with the type of investors that participate in these platforms. Beyond small retail investors as lenders, $\mathrm{P} 2 \mathrm{P}$ platforms have had to look at the more liquid wholesale markets to fund the multitude of consumer and SME loans. ${ }^{43}$ The reason for the drought of retail lenders investing in $\mathrm{P} 2 \mathrm{P}$ platforms is a regulatory one.

For these lenders, money deposited in more conventional banking institutions is traditionally protected by: (a) deposit insurance protection schemes, and (b) a lender of last resort system. ${ }^{44}$ These safety nets allow bank depositors to remain virtually unconcerned about the solvency of the bank, because their deposits are safeguarded, both ex-ante and ex-post, in the event of the bank's default. Conversely, as illustrated earlier by the example of the Manchester-based FinTech firm, there is no such regulatory protection afforded to investors in P2P platforms. Thus, faced with the choice between safe and low-yielding deposits with conventional banks on the one hand, and more risky but more rewarding investments in P2P loans on the other hand, most retail customers end up opting for the former.

Hence, the picture of a market that relies heavily on wholesale institutional investors in order to fund consumer and SME loans. ${ }^{45}$ As will be explained later in this section, the liquidity that is necessary to fund the volume of loan applications is achieved through the process of securitising P2P loans. ${ }^{46}$

In light of this, it is legitimate to question whether the simple idea at the heart of using technological platforms to directly connect lenders and borrowers, to effectively recreate an idea of financial intermediation, is encumbered by the nature of some $\mathrm{P} 2 \mathrm{P}$ companies. It is increasingly observed that $\mathrm{P} 2 \mathrm{P}$ companies can in many cases have a commercial nature ${ }^{47}$ which entails that they often enter into partnerships with traditional banking institutions. ${ }^{48}$ The extent to which P2P platforms become essentially the interface of banks or other financial institutions is still unclear. ${ }^{49}$ There is, however, as said earlier, an emerging trend in the UK that sees

\footnotetext{
43 An example of this can be seen in the recent fundraising of the notable P2P platform RateSetter, resulting in the floatation in the London Stock Exchange. Similarly, another platform, Funding Circle, had already tapped the wholesale market in a similar fashion. See Kleinman [45].

${ }^{44}$ See on this Ricks [52].

45 Supra Craughan et al. [19].

${ }^{46}$ Ibid.

47 As opposed to a social nature whereby their preeminent scope is to provide the online technological platform in order to facilitate lending. See Aveni [8].

48 Ibid.

49 There is some evidence though of successful FinTech platforms being taken over by large financial institutions and then being operated by them. See for instance Haslett [40].
}

P2P platforms securitising the loans originated through the platform. From a transactional perspective, this entails a break-up with respect to some of the roles and functions normally performed by the platform. ${ }^{50}$

Moreover, in a securitisation chain involving P2P loans, risks of low transparency related to the underlying loans tend to be augmented. ${ }^{51}$ It is trite to remember that in all types of securitisations there is a risk of moral hazard, because the originator may seek to lay off low-quality assets to investors in the capital markets. This type of risk could be magnified in P2P securitisations because of the longer transactional (and intermediation) chain. In turn, this could lead to market failures, because of the same agency problems that typically affect originators in securitisations at a time when they lower their underwriting standards, without having full awareness of the risks of the originated portfolio. ${ }^{52}$ Moreover, the repackaging of $\mathrm{P} 2 \mathrm{P}$ loans comes with the further difficulty to access and analyse the credit risk of individual underlying loans. These will have been rated through the platforms' scoring mechanisms, and it is unclear how they are incorporated into the more conventional rating mechanisms before being sold in the capital markets. ${ }^{53}$

The critical point here is that the resulting asymmetry of information, while being common in many other channels of financial intermediation, should be expected to be minimised on P2P platforms, especially in light of their reconceptualisation provided in "Reconceptualising FinTech, P2P lending and financial intermediation" section of this article.

Another relevant feature of $\mathrm{P} 2 \mathrm{P}$ platforms in the $\mathrm{UK}$ is that, given the advantageous structure of P2P loans-low transactions and operating costs, therefore lower interest rates to borrowers and higher rates of return to investorsa number of borrowers accessing the platforms have been doing so for the purpose of further extending credit to their own customers and thereby profiting from the difference between the interest paid on the platform and that charged to their borrowers. ${ }^{54}$ Beyond creating problems of excessive

\footnotetext{
50 The repayment of the loan for instance is in most cases performed by a servicer that is also in charge of other functions such as selecting the loans to be securitised and analysing the credits. See Timperio and Bear [56].

${ }^{51}$ It needs to be stressed though that, compared with traditional banking institutions, P2P platforms have anyway less information on their borrowers, and therefore, problems of asymmetric information tend to be greater than in the traditional banking system. Supra Giudici [36].

52 Supra Aquilina and Kraus, [1] 2016, p. 35.

${ }^{53}$ It will be remembered that in conventional securitisations, the resulting bonds are rated by credit rating agencies.

${ }^{54}$ See De Savorgnani [21]. It needs to be noted though that these borrowers accessing the $\mathrm{P} 2 \mathrm{P}$ platform for the purpose of lending to other borrowers would be required to operate with a banking authorisation as they would find themselves in a position akin to "accepting deposits" for regulatory purposes.
} 
credit creation, which are beyond the scope of this article, this practice presents a further layer of regulatory challenges that are analysed in the following sections, together with the structural information problems that may be undesired.

Before engaging with the discussion on the regulatory challenges in the UK, the following section provides an overview of the UK FinTech market, with some specific insight into the business model characterising the main P2P platforms.

\section{Business models and emerging risks}

A recent article published by $\mathrm{CNBC}$, commenting on the growth of the FinTech industry in Europe, unveiled a list of top fifty firms, which appeared to be dominated by UKbased companies. While the article provided a useful overview of the main players in the industry, it also clarified that, notwithstanding its diversity, the industry presents strong collaboration or ties with the mainstream banking industry. It was also inferred that this synergy will improve the efficiency of the services offered to financial consumers. ${ }^{55}$ Questions remain open as to whether these ties are sufficiently disclosed and whether they create risks of undesired interconnectedness. This is partly in line with what has been found by the Basel Committee (Bank for International Settlements), which stated in a recent report that banks are increasingly embracing financial technology and to that end they are relying on third-party service providers in order to support the tech-based financial service. ${ }^{56}$

So far, reference has been made to both FinTech and P2P platform, without clarifying the different business models adopted by different types of platforms. This section explains that a number of FinTech platforms are effectively operating like banks and that their balance sheet resembles closely that of banks. ${ }^{57}$ These entities are also licenced and regulated as banks $;^{58}$ therefore, there are no specific legal or regulatory questions that emerge for the purpose of this

\footnotetext{
55 See Ainger [2].

56 BCBS [12]. It is acknowledged in the report that in cases where banks outsource the technology service or product to a FinTech platform, they would remain accountable for the risks and liabilities related to the service or product. Questions of supervision would be less straightforward where the relationship between banks and FinTech platforms is less transparent.

57 Similarities with mainstream banks are represented for instance by entries such as debt securities on the assets side, and derivatives on the liabilities side. See Atom Annual Report [7], p. 39, and p. 41 , where the cash flow statement shows that the acquisition of debt securities increased from $£ 6,559,000$ in 2016 to $£ 71,650,000$ in 2017.

58 See Monzo Annual Report [48], p. 7; and Atom Annual Report [7], p. 12.
}

article. Such FinTech banks, for the purpose of illustration, are Monzo and Atom Bank. ${ }^{59}$

What more clearly embodies the idea of alternative financing channels is the intermediation taking place on $\mathrm{P} 2 \mathrm{P}$ platforms. ${ }^{60}$ While this market is heterogeneous and characterised by different business models, ${ }^{61}$ the purpose of this section is to highlight the main risks that emerge from the operation of the main P2P platforms. It is worth looking at Zopa, which is probably the first company to have adopted a business model grounded on the direct online-based matching of people looking for a loan on the one hand, with those looking for an investment on the other. ${ }^{62}$ Zopa only charges fees at three specific stages: an origination fee and a servicing fee are charged to the borrower when the loan facility is set up; a $1 \%$ fee is charged to investors when they want to sell their loan portfolio. ${ }^{63}$ The efficiency associated with this business model has attracted the attention of financial institutions, a number of which invest through the Zopa platform (and increasingly through other P2P companies). ${ }^{64}$ Beyond this, the association between mainstream banks and the FinTech industry is becoming increasingly evident because the former are responding to the disruptive competition posed by the latter largely through acquisitions and partnerships. ${ }^{65}$

The business risks that emerge in connection with $\mathrm{P} 2 \mathrm{P}$ platforms are difficult to locate for a number of reasons. Firstly, it needs to be remembered that they are subject to a lighter regulatory regime than fully licenced financial firms. Zopa for instance is authorised by the FCA specifically for P2P lending activities, ${ }^{66}$ but this does not entail the same level of regulatory oversight that pertains to fully licenced FinTech banks. Lighter regulatory oversight is also reflected in the narrower range of services offered by $\mathrm{P} 2 \mathrm{P}$ platforms, limited in the case of Zopa for instance to loans,

\footnotetext{
${ }^{59}$ Of course their activities are characterised by the digital mode of provision/relationship. They have also been defined by the Basel Committee as "challenger banks", essentially neo-banks with a "foot (or more) in the banking business and competing with mainstream banks through the employment of modernised and digitised relationship models". Supra BCBS [12], p. 17.

60 See Ainger [2].

${ }^{61}$ As an example, in some platforms investors choose directly individual P2P agreements, whereas in others it is the platform that allocated individual agreements to investors. See on this FCA [29].

${ }^{62}$ See "How Zopa Works" [43].

${ }^{63}$ Ibid.

${ }^{64}$ Roughly, 56\% of Zopa's investors are retail or individual, while the rest are institutional lenders. See www.zopa.com/lending/risk-marke ts.

65 See Arnold [6].

66 This is also known as Article $36 \mathrm{H}$ of the Financial Services and Markets Act 2000 (Regulated Activities Amendment No. 2 Order 2013), which deals specifically with operating an electronic system in relation to lending.
} 
debt consolidation, home improvements, car finance, weddings. ${ }^{67}$ Moreover, risks from the perspective of investors are usually categorised under simple classes of risks. ${ }^{68}$

Unlike FinTech banks, P2P platforms do not provide an outline of the risks that their operations can potentially trigger. This has implications with respect to their overall risk management and in particular the credit risk that their investors are exposed to. Zopa for instance does specify that issues of credit risk remain the lender's concern.

The problem of credit risk is tackled in a number of ways across different platforms. Funding Circle for instance suggests that credit risks are mitigated through a system of loan diversification whereby each loan is directed to a minimum number of lenders. ${ }^{69}$

Zopa was among the first companies to rely on a Safeguard Trust that provides lenders with protection in case the borrower fails to repay the loan, with the trust being funded with a percentage of the borrowing fee and loan servicing fee. $^{70}$

At RateSetter, credit risk mitigation strategies revolve around rigorous underwriting standards when borrowers apply for a loan, together with a diversified portfolio. RateSetter too has a Provision Fund, which represents a cushion against non-performing loans. ${ }^{71}$ Interestingly, RateSetter also includes a platform risk which covers the event of its ceased trading. In that case, a fully funded runoff plan would be in place and it would be administered by a third party, which would guarantee that the contracts,

\footnotetext{
${ }^{67}$ See www.zopa.com/loans. RateSetter, another prominent UKbased platform, specialises in channelling finance for personal loans, small businesses and property finance. See www.ratesetter.com/about us.

68 At Zopa, a core one yielding $4 \%$ and a plus one involving higher risk markets, yielding 4.6\%. See www.zopa.com/lending options for lenders include Individual Savings Account (ISA). Funding Circle states that they review the borrower's application and only approve creditworthy business, which are assessed by the platform through an internal assessment model. The assessment revolves around three pillars, namely initial eligibility criteria, statistical credit models and expert judgement based on manual assessment. See Funding Circle [34].

${ }^{69}$ See Funding Circle [34]. This is the advised investment pattern, and it is employed as the automated lending tool on the platform, whereby a loan of $£ 2000$ will be directed to at least 100 borrowers.

70 The Zopa Safeguard Trust in turn pays that amount to P2PS Limited which is the effective trustee holding the money for investors. If a default occurs, a claim is made by Zopa to the P2PS on behalf of the investors. Should P2PS decline to pay the lender, Zopa will take action by commencing a debt recovery procedure against the individual borrower. See www.zopa.com/lending/what-are-the-risks.

${ }^{71} \mathrm{See}$ https://invest.ratesetter.com/invest/everyday-account/ where it is stated that the Provision Fund is large enough to withstand credit losses of up to $112 \%$; above that level of losses, the Fund would be depleted but investors capital would remain intact, even though they would earn less than expected. When credit losses amount to above $278 \%$ of expected losses, investors would start losing capital.
}

and underlying repayments, between borrowers and lenders remain in place. ${ }^{72}$

However, these mechanisms do not amount to a form of deposit insurance protection, nor to a lender of last resort mechanism. Investments in P2P platforms are not covered in fact by the Financial Services Compensation Scheme, as would be the case for bank deposits. Nor are the platforms regulated and licenced like banks for the purpose of central bank liquidity protection.

Lastly, with respect to the risk of the underlying loans, Zopa states that it applies a number of minimum criteria before allowing a potential borrower to be matched with a lender. In essence, Zopa performs a preliminary credit check on the borrower, and if this is successful, it then classifies the loan into different risk markets (from $A^{*}$ to $E$ ) which represent a number of factors, such as the likelihood of the debts being repaid on time, the borrower credit history and their debt-to-income ratio. ${ }^{73}$ Funding Circle states that they review the borrower's application and only approve creditworthy business, which are assessed by the platform through an internal assessment model. The assessment revolves around three pillars, namely initial eligibility criteria, statistical credit models and expert judgement based on manual assessment. $^{74}$

\section{Regulatory challenges: addressing questions of credit risk, interconnectedness and systemic risk}

While the platforms mentioned in the previous section represent the upper end of the P2P market, a number of legal and regulatory issues are now surfacing, reflecting some of the fragilities intrinsic to this market. ${ }^{75}$ These revolve around the fundamental questions of credit risk assessment and credit risk management, which have been signposted throughout this article. Beyond harming investors in the $\mathrm{P} 2 \mathrm{P}$ market, who bear the credit risk of the underlying loans, at a higher policy level the question is whether mass defaults in this market, and the interconnectedness with wholesale channels of finance, can translate into a systemic problem.

The above begs two related questions. First, whether investors should be allowed to be exposed to a level of credit risk that admittedly is still difficult to fully appreciate given the character of the underlying loans and the absence of an

\footnotetext{
72 Ibid.

${ }^{73}$ See www.zopa.com/lending/risk-markets.

${ }^{74}$ See Funding Circle [34].

${ }^{75}$ Reference here is made to the increasing defaults in P2P loans, which raises the question of whether investors in these platforms were aware of the level of risk they were taking. See Williams [58].
} 
established and reliable rating mechanism. The second question is whether the other increasing trend that sees platforms tapping the wholesale market through securitisation can create problems of interconnectedness and systemic risk. ${ }^{76}$

Interestingly in the UK, some of the above regulatory concerns have been picked up by the FCA that has launched a consultation to propose changes to the regulation of $\mathrm{P} 2 \mathrm{P}$ platforms. This section addresses the questions posed in the previous paragraph by developing a critical examination of the attendant regulatory challenges and how they are regulated in the UK. The discussion is divided into two parts, each reflecting the two questions posed earlier.

Before moving to that more specific regulatory analysis, it is useful to remember that the FCA has since 2014 jurisdiction over P2P platforms. P2P platforms are in this sense under specific requirements to have an operational website, and to maintain minimum financial resources. ${ }^{77}$ Moreover, through its "Innovation Hub" the FCA is promoting a policy that favours disruptive innovation through new financial technologies. ${ }^{78}$ This policy is particularly sensitive to the difficulties that technology firms may experience when complying with financial regulation, and therefore, it is aimed at reducing regulatory costs. ${ }^{79}$ Admittedly, the FCA's approach may have resulted initially in a facilitative (or enabling) regulatory framework, which the regulator now feels may necessitate some adjustment. ${ }^{80}$

\section{Credit risk and consumer protection}

The analysis conducted in the previous section highlighted the fundamental problem of investor protection. In particular, issues related to the governance and disclosure of data analytics were recently raised by both the FSB and the FCA. The former pointed to the complexity and opacity of the relevant models, which make their assessment difficult for both market players and regulatory authorities. ${ }^{81}$ Similarly, the FCA expressed concerns on the lack of data

\footnotetext{
76 Funding Circle for instance came to prominence in 2018 for its second securitisation programme, related to over four thousand loans directed to a range of UK SMEs. See Ali [3].

77 These take the shape of minimum capital requirement, which is normally $£ 20,000$ and can increase to $£ 50,000$ or to a percentage of the funds loaned by the platforms. See Cummings [20].

78 See FCA Innovation Hub (website) [28].

79 See in this sense Starks [54]; and Zetzsche et al. [60].

${ }^{80}$ For some comments on these proposed changes, see different reactions reflected in Stevenson [55]; and FT [33].

${ }^{81}$ FSB [30]. In this same report, the FSB suggests that lack of robustness in the assessment of relevant date, and thus in the credit quality of underlying exposures, could lead to procyclical behaviours among both lenders and borrowers, due also to the limited incentives that platforms have to accurately assess credit quality.
}

standardisation, which may limit the benefit of technology in the first instance, and it can certainly impede the tasks of the regulatory authority. ${ }^{82}$ From market players' perspective, the above problem proposes again questions of credit risk, because the rating provided by the platforms and disclosed to investors is not sufficient to protect lenders from the variability of default and loss over the business cycle-notwithstanding the platforms' practice to diversify the loans among many borrowers. ${ }^{83}$

This section proceeds by analysing the regulatory proposals brought by the FCA in relation to specific problems emerging from the business model of $\mathrm{P} 2 \mathrm{P}$ platforms.

\section{Risk management: ensuring that platforms price investments accurately}

Many of the regulatory issues related to credit risk have been subject to the FCA review above referenced. It is worth noting that P2P platforms are already required, under current FCA rules, to conduct their business with due skill care and diligence, with particular emphasis on their internal system of risk management. ${ }^{84}$ This general duty is applied in connection with a requirement for the platforms to have a robust governance arrangement, which for the purpose of $\mathrm{P} 2 \mathrm{P}$ platforms comprises the identification, management and monitoring of the risks that the platform may be exposed to. ${ }^{85}$

In addition to these existing overarching duties, the FCA has taken stock of the more specific risks that emerge in connection with P2Ps' business, particularly with respect to the credit risk that they price and offer to investors. The FCA therefore in its consultative proposal is putting forward the case for more specific risk management requirements in relation to the pricing of loans originated by the platforms.

In particular, the FCA has looked closely at different business models, and it has concluded that when platforms set the price of the agreement, investors clearly rely on the platform for a fair and appropriate pricing of the agreement. Thus, more prescriptive risk management requirements should be in place, including duties to: (1) gather sufficient information about the borrower in order to competently assess its credit risk; (2) categorise systematically borrowers by their credit risk, taking into account probability of default and loss-given default; (3) set the price of the agreement in a way that fairly reflects the risk profile of the borrower. ${ }^{86}$

\footnotetext{
82 See FCA [25].

${ }^{83}$ Milne and Parboteeah [47].

${ }^{84}$ See FCA PRIN 2.1.1R (03/01/2018), available at https://www. handbook.fca.org.uk/handbook/PRIN/2/1.html.

${ }^{85}$ See FCA SYSC 4.1.1R (03/01/2018), available at https://www. handbook.fca.org.uk/handbook/SYSC/4/1.html.

${ }^{86}$ FCA [29], p. 34.
} 
Moreover, with respect to more sophisticated business models, whereby platforms offer a target rate of return to investors for a loan portfolio that the platform manages, the FCA proposes that the return advertised to investors should have a reasonable basis to be achieved and therefore advertised. ${ }^{87}$ In this context, the FCA also prescribes that when platforms facilitate a secondary market for loans, these have to be allocated according to investors' initial risk preferences. $^{88}$

Enhanced risk management functions in $\mathrm{P} 2 \mathrm{P}$ platforms should, according to the FCA consultation, also have regard to the complexity of the platform and the range of services it offers. An independent risk management function is envisaged in order to implement and monitor the adequacy and effectiveness of the relevant policies and procedures, with a duty to advise the platform's senior management on matters of risk. ${ }^{89}$

From a different perspective, the FCA is also looking at strengthening corporate governance standards within $\mathrm{P} 2 \mathrm{P}$ platforms as it is proposing that those with responsibilities for the establishment of the platform's risk management framework should be persons approved for a significant function, such as a director, under the Senior Managers and Certification Regime (SMCR).$^{90}$ This requirement would entail that such directors would have to be suitably qualified and pass the fit-and-proper test that applies for approved persons.

\section{Marketing restrictions: ensuring that investors limit their potential risk exposures}

A more controversial aspect of the FCA's consultation is related to the proposed restrictions on the marketing of loans that are deemed intrinsically risky. This move is clearly informed by a desire to protect financial consumers in a fashion that a number of commentators have critiqued as paternalistic. ${ }^{91}$ The FCA in particular is concerned that risks and rewards are not balanced appropriately on $\mathrm{P} 2 \mathrm{P}$ platforms and that investors are generally not capable of assessing their risk exposure due to the way in which the platforms operate. ${ }^{92}$

The FCA is therefore proposing to make investors less overexposed to P2P loans and limit their potential losses. In

\footnotetext{
87 Ibid, p. 35.

88 Ibid. investors should not in other words be exposed to risk criteria that they had not signed up to.

${ }^{89}$ Ibid, p. 38.

90 Ibid, p. 40. See also on the SM\&CR FCA "Senior Managers and Certification Regime", 11/10/2018, available at https://www.fca.org. uk/firms/senior-managers-certification-regime.

91 Stevenson [55].

92 FCA [29], p. 41. The FCA in particular refers to complexities deriving from the administration, servicing and managing of the underlying loans.
}

particular, the proposal revolves around the platforms' duty to only communicate promotions to investors that for the purpose of the FCA classifications: (a) are certified or selfcertified as sophisticated, (b) are certified as high net worth, (c) will receive regulated investment advice, (d) certify that they will not invest more than $10 \%$ of their net investible portfolio in $\mathrm{P} 2 \mathrm{P}$ agreements. ${ }^{93}$

\section{Wind-down arrangements}

It was reiterated throughout this article that $\mathrm{P} 2 \mathrm{P}$ platforms do not hold their clients' money, and they are not directly affected by the credit risk of the platform's borrowers. As a consequence, capital requirements are substantially lower than in other investment firms. It was also stressed in "The UK P2P market" section though that platforms do have in place wind-down arrangements. ${ }^{94}$ These are aimed at ensuring that in the event of the platform ceasing to exist, the underlying loans would continue to be managed and administered.$^{95}$ While currently P2P platforms are required to take reasonable steps to ensure that the above arrangements are in place (as it is reflected in the analysis conducted in "The UK P2P market" section), the FCA is proposing to strengthen this requirement by clarifying that platforms must have arrangements in place to ensure that the underlying agreements will have a reasonable likelihood of being managed/ administered. ${ }^{96}$

\section{Disclosure of investment risks}

Last but not least, the interest of $\mathrm{P} 2 \mathrm{P}$ investors is ideally protected by an adequate system of disclosure that allows lenders to understand the investment's risks and opportunities

\footnotetext{
$\overline{93}$ Ibid, p. 42. For the purpose of the FCA Handbook classifications, the above categories of investors fall under retail clients. In the case of non-advised retail clients, the FCA is also proposing that platforms should anyway comply with conduct of business rules on appropriateness (COBS 10), which is aimed at assessing ex-ante whether investors have the knowledge or experience to understand the risks of the investment.

${ }^{94}$ For the purpose of the current FCA authorisation, platforms should also have a resolution plan in place, so that in the event of their failure, the underlying loans contracts can be managed to maturity.

95 In the absence of these arrangements, investors would be exposed to a platform credit risk that would be similar to the credit risk of the underlying loans.

${ }^{96}$ FCA [29], pp. 43, 44. The FCA refers to these arrangements as "P2P resolution manuals", which would have a function similar to the "living wills" of large financial institutions, in that they have to provide information on how to facilitate the resolution of the platform in the event of its insolvency. The FCA is also contemplating, as a possible addition to the above prudential regime, mandating the minimum capital requirements for $\mathrm{P} 2 \mathrm{P}$ platforms.
} 
and the role of the platform. Currently, under COBS rules, $\mathrm{P} 2 \mathrm{P}$ platforms are already under a duty to communicate with clients in a fair, clear and not misleading way, ${ }^{97}$ and to provide investors with information about the nature and risks of the investment. ${ }^{98}$

Beyond these requirements, the FCA is proposing an increased and more effective system of disclosure. Given the diversity of business models in the P2P market and the poor comparability of relevant data, the aim is to enable investors to appraise investment opportunities and risks across platforms, and also to understand the nature of the service offered by each platform. ${ }^{99}$

These requirements are also reinforced in the more specific context of investment information, where P2P platforms are currently bound by conduct of business rules to provide investors with a description of the risks that they are exposed to. ${ }^{100}$ Moreover, the current framework sets out guidance clarifying what $\mathrm{P} 2 \mathrm{P}$ platforms should include in their disclosure in relation to investment risk, ${ }^{101}$ and the FCA is proposing to transform this guidance into mandatory rules.

The FCA proposals in the sphere of disclosure are even more far reaching when it comes to ensuring that investors have access to all relevant information that relates to transparency of platform fees and different investment opportunities. This set of information becomes particularly important when investors are faced with different business models adopted by platforms. ${ }^{102}$ Investment disclosure is also conceived under the proposals as a means to allow customers to access details of the agreements they have entered into on an ongoing basis. ${ }^{103}$

\section{Interconnectedness and systemic risk}

In a recent speech, the Head of the Bank of England, Mark Carney, admitted that the potential benefits of the FinTech revolution need to be analysed in conjunction with the possible risks emerging from these new channels of financial

\footnotetext{
97 COBS 4.2.

98 COBS 14.3.

99 FCA Consultation 2018, p. 45.

100 COBS 2.2.1R.

101 COBS 14.3.7AG(1)-(10).
}

102 FCA Consultation Paper 2018, pp. 47, 48, 49. Reference here is made specifically to platforms where investors choose individual $\mathrm{P} 2 \mathrm{P}$ agreements, vis-à-vis platforms that directly allocate agreements to investors, whereby the platform manages a portfolio of loans in order to achieve a target rate.

103 Ibid. p. 49. Ongoing disclosure becomes particularly relevant in the context of the secondary market where platforms should perform a valuation of the $\mathrm{P} 2 \mathrm{P}$ agreement following a default. intermediation. ${ }^{104}$ With respect to $\mathrm{P} 2 \mathrm{P}$ platforms, it is important to understand whether systemic risk may become a matter of concern given the expansion of the platforms to wholesale channels of intermediation, and particularly to the securitisation market. ${ }^{105}$

It was stressed earlier in this article that the $\mathrm{P} 2 \mathrm{P}$ market has been characterised from the outset by the involvement of institutional lenders as providers of finance, due to the scarcity of retail lenders to match borrowers' demand for finance. While the FCA proposals discussed in the previous section may mitigate two problems affecting retail investors, namely their difficulty to assess risks over the business cycle, ${ }^{106}$ and the risks related to the platform's default, the proposals also make it more difficult to market P2P loans to retail borrowers. This entails if anything an ever increasing reliance on sophisticated and/or wholesale investors.

At the same time, the practice of securitising P2P loans has already boomed in the USA, ${ }^{107}$ while in the UK, the credit rating agency Moody's predicted in 2016 that platforms would increasingly tap the wholesale market through securitisation in order to grow their business. ${ }^{108}$

One straightforward application of securitisation in the context of P2P loans is the pooling of underlying loans in a securitisation vehicle (SPV) conducted by P2P investors. In the USA for instance, this practice has seen a number of large institutional investors (among which hedge funds, asset managers, banks) acquiring large portfolios of P2P loans and then securitising them in order to increase their leverage positions. ${ }^{109}$ In essence, this further intermediation chain develops outside the platform, and it is to an extent consistent with the idea of facilitating a secondary market for P2P loans, which most platforms have encouraged.

What is more problematic though is the direct participation of $\mathrm{P} 2 \mathrm{P}$ platforms as originators in the securitisation chain. This has recently become the case in the UK with deals involving Funding Circle ${ }^{110}$ and Zopa. ${ }^{111}$

\footnotetext{
104 Supra Carney [16].

105 Ibid; see also Milne and Parboteeah [47].

106 Supra Milne and Parboteeah [47], pp. 24-25.

107 Peer2Peer Finance News [50].

108 Peer2Peer Finance News [51]. Apparently, as of March 2018, this prediction of a securitisation boom in $\mathrm{P} 2 \mathrm{P}$ loans is yet to materialise, and one reason ascribed to the small numbers of securitisation deals in the market is the size of each deal, which should be of at least $£ 1$ bn for a securitisation to be economically viable. See Shoffman [53].

109 Devasabai [22]. It is observed in this article that P2P lending has turned in the USA into "hedge fund-to-consumer lending".

110 Brunetti [14]. "The platform kicked off a new business avenue for the whole UK sector when it became the first to package its loans into a multi-tranche bond, in collaboration with Deutsche Bank and KLS Diversified Asset Management".

111 Hale [37]. In this case though, the situation seems to be closer to the previous scenario because the loans were being held by an institu-
} tional fund, P2P Global Investments PLC. 
For the sake of clarity of analysis, securitisation is a transactional process aimed at pooling assets, in this case $\mathrm{P} 2 \mathrm{P}$ loans. These are sold by the originator, which as explained earlier can either be a $\mathrm{P} 2 \mathrm{P}$ investor ${ }^{112}$ or the platform itself, ${ }^{113}$ to a special purpose vehicle (SPV). The SPV issues bond-like securities to investors in the capital markets, whereby the securitised bonds are secured over the P2P loans held by the SPV. Thus, the return for capital markets investors (hedge funds for instance) is linked to the contractual payments made by the underlying obligors in the $\mathrm{P} 2 \mathrm{P}$ loans. Credit rating agencies are typically involved with the rating of securitised bonds. ${ }^{114}$

The direct involvement of $\mathrm{P} 2 \mathrm{P}$ platforms as originators would lead to their rapid growth in the market, as they may resort to securitisation chiefly in order to inflate the volume of loans originated. ${ }^{115}$ Given that this mostly occurs before the realistic strength, and weakness of the market can be weighed throughout a whole business cycle, there emerge concerns about the quality of underwriting standards, which are not consistent across platforms, and may well be lowered, leading to the same problems experienced before 2008 in the mortgage market. ${ }^{116}$

In light of the reconceptualisation of financial intermediation provided in "Reconceptualising FinTech, P2P lending and financial intermediation" section, the practice of securitising P2P loans entails a fundamental break-up in the role of the platform. ${ }^{117}$ Overarching questions of transparency and credit risk may also become more problematic to deal with. Securitising P2P loans presents exacerbated problems of moral hazard given the intrinsic low transparency of the underlying assets and the lack of standardised data. Originators here, whether that is the platform or the lender, could well seek to lay off low-quality assets in the capital markets,

\footnotetext{
112 The P2P investor would in this case securitise the loans that he/ she has entered into.

113 The P2P platform would in this case securitise the loans that have not been subscribed by any investors.

${ }^{114}$ See generally on securitisation: Bavoso [9].

115 Where the originator is an investor in P2P loans, this is due primarily to the removal of assets from its balance sheet, which creates "regulatory capital" and therefore the opportunity to subscribe more loans. Where the originator is the platform, securitisation allows tapping directly the capital markets and therefore matching borrowers' demands for finance, without the loans having been matched on the platform. Securitisation is also a tool employed to transform and maximise funding and liquidity risks.

116 Supra Devasabai [22], pp. 18-21.

117 It is observed that this may become problematic for investors. For instance, the repayment of the loan is in most cases performed by a servicer that is also in charge of other functions such as selecting the loans to be securitised and analysing the credits. See Timperio and Bear [56]. See on this also Hale [38]. It is observed here too that platforms may not have an economic stake in the securitisation (as was the case with Funding Circle, which acted as servicer though).
}

and the employment of securitisation would further complicate appraising the credit risk of individual underlying loans due to the longer intermediation chain. ${ }^{118}$

While questions of credit risk and investor protection have been addressed by the FCA in its proposal for a new regulatory framework, dangers flowing from the interconnectedness of P2P platforms with wholesale channels have remained outside the scope of the FCA's radar. It has also recently been suggested that the limited size of the FinTech market in the UK pre-empts questions of systemic stability. Moreover, the Financial Stability Board (FSB) recently stressed that the nature of $\mathrm{P} 2 \mathrm{P}$ platforms is that of agents or brokers and as such they do not engage with leverage and liquidity risks that are typical of banks, ${ }^{119}$ and that are normally associated with systemic risks.

It was also explained in "The UK P2P market" section though that platforms do adopt different business models, which entails that some form of maturity and liquidity risks may arise by virtue of the type of service offered by the platform. Carney also stated that undesired increases in leverage could also be caused by the interconnectedness with other areas of financial markets (such as the wholesale channel). ${ }^{120}$ Some P2P platforms for instance provide some form of liquidity services, ${ }^{121}$ but unlike banks they do so without having access to central bank liquidity facility or to funding sources available in the money market.

Similarly, the concerns raised by Carney could materialise if a large percentage of wholesale investors in the platforms came from the banking sector. This would exacerbate the effect of interconnectedness and in turn would trigger financial stability concerns. In particular, Milne and Parboteeah observe that financial institutions investing in illiquid P2P loans on their assets side and matching their positions with short-term funding sources from the money market on their liabilities side could create funding risks similar to those experienced in 2008 with the run on the repo market. ${ }^{122}$

\footnotetext{
118 Supra Timperio and Bear [56].

119 See FSB and the Committee on the Global Financial System (CGFS) [32].

120 Supra Carney [16].

121 From the illustration provided in the earlier section, it will be remembered that Funding Circle allows early repayments of business loans, which reflect a sort of rolling-over facility. Most platforms also allow or facilitate the sale of loans by investors, often for a fee. See on this also Milne and Parboteeah [47], p. 21.

122 Supra Milne and Parboteeah [47], p. 22. Elsewhere in their paper, Milne and Parboteeah point out that liquidity risks could be exacerbated if large numbers of institutional investors were to withdraw their loans at critical stages of the business cycle, and thus lead to self-reinforcing collapses of prices. See p. 25.
} 
To further illustrate this analogy, let us imagine that the trend that sees $\mathrm{P} 2 \mathrm{P}$ platforms tapping the wholesale market, with institutional investors matching borrowers, will continue. These institutional investors, such as banks or hedge funds, would become exposed to P2P loans and securitised bonds backed by P2P loans on their assets side. On their liabilities side, they would most likely rely on short-term sources of liquidity, such as for instance repo agreements. ${ }^{123}$ Should the confidence in the P2P market collapse, or even just diminish, due to the increasing default rates of the underlying loans, the parallel with the mortgage/housing market in the pre-crisis years would materialise. Once this scenario occurred, funding sources for the P2P market would dry up and it would thus become highly difficult to either originate loans or rollover existing ones.

Thus, to get back to the previous point, securitisation would certainly boost the volume of $\mathrm{P} 2 \mathrm{P}$ loans origination in the short-term. This growth, however, would substantially lengthen and complicate an intermediation chain that, by nature, was conceived as straightforward and streamlined. Moreover, as explained in the previous paragraph, problems of financial stability and systemic risk would be heightened due to the magnified interconnectedness with wholesale channels of finance. It is worth remembering that the policy aim behind FinTech generally, and $\mathrm{P} 2 \mathrm{P}$ platforms specifically, is to decentralise the financial system and elicit a distribution of risks among a wider range of market players, away from systemic institutions. ${ }^{124}$ From a regulatory standpoint, that is why longer intermediation chains on $\mathrm{P} 2 \mathrm{P}$ platforms deserve to be monitored carefully, as they can potentially defy the above aim to spread risks effectively. ${ }^{125}$

\section{Concluding remarks}

This article takes a cautious stance on the recent growth of the FinTech phenomenon in the UK and in particular of alternative, market-based financial intermediation taking place on P2P platforms. While the UK market is not the largest in the world, it has experienced a rapid development, due partly to a favourable regulatory environment, where the FCA fashioned an encouraging and facilitative regime. This was represented by the Innovation Hub, and overall

\footnotetext{
123 To understand the risks intrinsic in this financing structure, see Bavoso [10], pp. 9-12.

124 See FSB and the Committee on the Global Financial System (CGFS) [32].

125 The FSB has also stated that decentralisation may have counterproductive effect because new channels of credit could lead to nontraditional market players becoming systemically important. See FSB [30].
}

by a flexible regulatory framework that was sensitive of the business needs of small, tech-based start-ups.

Following in the US footsteps, much of the UK P2P market grew, either through the consolidation of technology platforms into larger financial institutions, or through the expansion of the P2P business into wholesale channels of finance. ${ }^{126}$ At the same time though, recent events sparked some degree of scepticism into the long-term stability of this market. Increases in the default of P2P loans led the FCA to question whether default rates would actually keep increasing once the full economic cycle goes by. ${ }^{127}$ The intrinsic fragility of the market also triggered concerns for investors, and specifically the extent to which they are able to weigh the riskiness of the investment, given the poor comparability of data related to the underlying loans. The recent FCA proposal, analysed in "Regulatory challenges: addressing questions of credit risk, interconnectedness and systemic risk" section of this article, needs to be seen as a response to some of these concerns.

The FCA in particular tackles with some vigour issues of credit risk and investor protection. In doing so, it sets much higher regulatory standards on $\mathrm{P} 2 \mathrm{P}$ platforms, which among other things may also be required to have minimum corporate governance standards in place. Following on from the analysis conducted in "Regulatory challenges: addressing questions of credit risk, interconnectedness and systemic risk" section, a legitimate question would be whether the new regulatory constraints will put the platforms under excessive pressure, making their synergy with large financial institution inevitable.

Similarly, some of the marketing restrictions proposed by the FCA would further diminish the extent to which retail investors can participate in $\mathrm{P} 2 \mathrm{P}$ platforms. Hence, it is likely that P2P platform will increasingly rely on institutional investors and on wholesale channels of finance such as securitisation.

As explained in the previous section, the employment of securitisation presents a number of regulatory questions that have not been specifically addressed by the FCA in its proposals. The problems that are likely to emerge are twodimensional and could be classified firstly as micro-issues, related to increased asymmetry of information and therefore more problematic due diligence and credit risk assessment. These problems may be partly mitigated by the FCA's proposed measures on investor protection, especially to the

\footnotetext{
126 The news of Zopa being granted a full banking licence in December 2018 reflects somewhat both of these trends. See Coulter [18]. Effectively Zopa embraced a group organisation under which full banking services operate alongside the $\mathrm{P} 2 \mathrm{P}$ ones.

127 Supra FCA Consultation Paper 2018, p. 41.
} 
extent that retail investors are protected against too risky exposures.

Admittedly, there is not much in the UK regulatory framework that deals specifically with the second dimension of regulatory problems, which can be classified as macroissues. These relate to the interconnectedness of P2P platforms with more risky and opaque channels of intermediations in wholesale funding markets. Instead, it appears that there is a widespread acceptance of the need to allow the market to grow and to resort to securitisation as a source of finance.

Undoubtedly, beyond the risks associated with this pattern of growth, of which "Regulatory challenges: addressing questions of credit risk, interconnectedness and systemic risk" section has provided some analysis, a more fundamental problem seems to be the ensuing reconceptualisation of $\mathrm{P} 2 \mathrm{P}$ finance. While in "Reconceptualising FinTech, P2P lending and financial intermediation" section it was observed that $\mathrm{P} 2 \mathrm{P}$ intermediation offers, in its more straightforward application, the type of allocative and intermediation functions that banks no longer perform, the development revolving around securitisation compromises the simplicity that is necessary for that concept to be implemented properly.

In line with this last consideration, it is legitimate to question the long-term sustainability of $\mathrm{P} 2 \mathrm{P}$ lending and whether it will survive the initial hype that is more generally surrounding the FinTech phenomenon. More importantly, there emerge questions of financial stability that threaten the health of the financial ecosystem as a whole. This would be particularly the case if the growth of $\mathrm{P} 2 \mathrm{P}$ finance through wholesale channels went unchecked by regulators. A concern this last one that is highly reminiscent of the doubts expressed by J. K. Galbraith in 1990.

Open Access This article is distributed under the terms of the Creative Commons Attribution 4.0 International License (http://creativeco mmons.org/licenses/by/4.0/), which permits unrestricted use, distribution, and reproduction in any medium, provided you give appropriate credit to the original author(s) and the source, provide a link to the Creative Commons license, and indicate if changes were made.

\section{References}

1. Aquilina, M., and W. Kraus. 2016. Market-based finance: its contributions and emerging issues. FCA Occasional Paper, 18 May 2016.

2. Ainger, N. 2017. Here are the 50 hottest Fintech firms in Europe right now. $C N B C$. https://www.cnbc.com/2017/06/07/fintech50list-here-are-the-50-hottest-fintech-firms-in-europe-right-now. html. 7 June 2017.

3. Ali, A. 2018. Funding circle portfolio priced tight in second SBOLT deal. Global Capital, https://www.globalcapital.com/artic le/b181fps1yvzv0x/funding-circle-portfolio-priced-tight-in-secon d-sbolt-deal. 3 May 2018.
4. Anderson, N., M. Brooke, M. Hume, and M. Kurtosiova. 2015. A European Capital Markets Union: Implications for growth and stability. In Bank of England Financial Stability Paper no. 33.

5. Arner, D., J. Barberis, and R. Buckley. 2016. The evolution of FinTech: a new post-crisis paradigm? In University of New South Wales Law Research Series, 6-7, vol. 62.

6. Arnold, M. 2018. Five ways banks are responding to the fintech threat. Financial times, https://www.ft.com/content/d0ab6b84c183-11e8-84cd-9e601db069b8. 12 Nov 2018.

7. Atom Annual Report, 2016-17.

8. Aveni, T. New insights into an evolving P2P lending industry: how shifts in roles and risks are shaping the industry. Credit Suisse/ Positive Planet, August 2015

9. Bavoso, V. 2013. Financial innovation and structured finance: The case of securitisation. Company Lawyer 34(1): 3-12.

10. Bavoso, V. 2018. Market-based finance, debt and systemic risk: A critique of the EU capital markets union. Accounting Economics and Law: A Convivium. https://doi.org/10.1515/ael-2017-0039

11. BBC. 2018. eBay drops PayPal as first choice for payments, $1 \mathrm{Feb}$ 2018. Available at http://www.bbc.co.uk/news/business-42905465.

12. BCBS. 2018. Sound Practices-Implications of FinTech Developments for Banks and Bank Supervisors, BIS Sound Practices, February 2018.

13. Beioley, K. 2018. Peer-to-peer lender collateral enters administration. Financial Times. https://www.ft.com/content/5568a 87a-1d36-11e8-956a-43db76e69936. 1 Mar 2018.

14. Brunetti, A. 2017. Funding circle's SME securitisation wins higher ratings. Peer2Peer Finance News. 16 Mar 2017. Available at http://www.p2pfinancenews.co.uk/2017/03/16/funding-circlessme-securitisation-wins-higher-ratings/.

15. Buckley, R. 2015. The changing nature of banking and why it matters. In Rethinking global finance and its regulation, eds. Buckley, Avgouleas and Arner, Cambridge: Cambridge University Press.

16. Carney, M. 2017. The promise of FinTech - something new under the sun?. In Speech, January 25, 2017. Available at https://www. bis.org/review/r170126b.pdf

17. Claessens, S., J. Frost, G. Turner, and F. Zhu. 2018. Fintech credit markets around the world: Size, drivers and policy issues. BIS Quarterly Review, 23 Sept 2018.

18. Coulter, M. 2018. P2P lender Zopa granted full UK banking licence. Financial Times. 4 Dec 2018. Available at https://www. ft.com/content/a2e0b6fa-f720-11e8-8b7c-6fa24bd5409c.

19. Craughan, J., D. Palmer, and E. Reid. 2015. Online lending platforms and securitisation: Bringing the wholesale market to the Individual. Journal of International Banking and Financial Law 6: 348 .

20. Cummings. 2015. Crowdfunding and FCA Authorisation, November 2015. Available at http://www.cummingslaw.com/publicatio ns/CL_Crowdfunding-FCA-Authorisation-1015.pdf.

21. De Savorgnani, M. 2017. Peer-to-peer lending: The shadow of banking regulation hangs over (unsuspecting) borrowers. Butterworths Journal of International Banking and Financial Law, 414.

22. Devasabai, K. 2014. A loan in the dark. Risk 18-21.

23. European Commission. Building a Capital Markets Union accompanying the Green Paper, COM 2015/63.

24. European Commission. Regulation on European Crowdfunding Service Providers for Business, COM (2018) 113 Final.

25. FCA. 2016. Feedback statement: Call for input on supporting the development and adopters of RegTech, FS16/4. 20 July 2016. Available at https://www.fca.org.uk/publications/feedback-state ments/fs 16-4-feedback-statement-call-input-supporting-devel opment-and.

26. FCA. 2017. Innovating for the future: the next phase of Project Innovate, 10 Nov 2017, Available at https://www.fca.org.uk/news/ speeches/innovating-future-next-phase-project-innovate. 
27. FCA. 2018. Innovate and innovation hub, 20 Sept 2018, Available at https://www.fca.org.uk/news/speeches/innovating-future-nextphase-project-innovate

28. FCA Innovation Hub (website), https://www.fca.org.uk/firms /innovate-innovation-hub; https://www.fca.org.uk/firms/innov ate-innovation-hub/next-steps.

29. FCA. 2018. Loan-based ('peer-to-peer') and investment-based crowdfunding platforms: Feedback on our post implementation review and proposed changes to the regulatory framework. Consultation Paper CP18/20, July 2018, p. 48.

30. FSB. 2017. Financial stability implications from FinTech, 27 June 2017-07-04.

31. FSB. 2017. Financial stability implications from FinTech - supervisory and regulatory authorities issues that merit authorities' attention, 27 June 2017, p. 1. Available at http://www.fsb.org/ wp-content/uploads/R270617.pdf.

32. FSB and The Committee on the Global Financial System (CGFS). 2017. FinTech credit: market structure, Business models and financial stability implications, p. 30. 22 May 2017.

33. FT. 2018. Peer-toPeer lending needs tighter regulation. Financial Times, 11 Sept 2018.

34. Funding Circle. 2017. Getting started as an investor - a guide for investors, pp. 4, 6 .

35. Galbraith J.K. 1990. A short history of financial Euphoria, Penguin.

36. Giudici, P. 2018. Fin-Tech: Research challenges in financial supervision and technological compliance. Frontiers in Artificial Intelligence. https://www.frontiersin.org/articles/10.3389/ frai.2018.00001/full. 5 Nov 2018.

37. Hale, T. 2016. Debut securitisation for Zopa loans. 26 Sept 2016. Available at https://www.ft.com/content/c401b6ef-5394-333cbb9e-d89aa3845b91.

38. Hale, T. 2016. Does securitisation of online loans have a future in Europe? Financial Times, 10 May 2016. Available at https://www. ft.com/content/da09358c-1602-11e6-9d98-00386a18e39d.

39. Hale, T. 2016. Funding circle to tap securitisation market. Financial Times. https://www.ft.com/content/69f32f55-ce38-3fdf-847474cacdcb31f9. 14 Apr 2016.

40. Haslett, E. London fintech star Monzo is fending off one takeover offer each month. City AM. 10 Oct 2017. Available at http://www. cityam.com/273523/london-fintech-star-monzo-fending-off-onetakeover-offer.

41. Havrylchyk, O. 2018. Regulatory framework for the loan-based crowdfunding platforms. OECD Economics Department Working Papers No. 1513.

42. Hockett, R., and S. Omarova. 2017. The finance franchise. Cornell Law Review 102: 1143.

43. How Zopa Works at www.zopa.com/about/how-zopa-works

44. Jaffer, S., N. Morris, E. Sawbridge, and D. Vines. 2014. How changes to the financial services industry eroded trust. In Capital Failure: Rebuilding Trust in Financial Services, ed. N. Morris and D. Vines. Oxford: Oxford University Press.

45. Kleinman, M. 2018. Peer-to-peer lender Ratesetter in talks about $£ 30 \mathrm{~m}$ fundraising. SkyNews, https://news.sky.com/story/peer-topeer-lender-ratesetter-in-talks-about-30m-fundraising-11408078. 17 June 2018.

46. McLeay, M., A. Radia, and R. Thomas. 2014. Money creation in the modern economy. Bank of England Quarterly Bulleting Q1: 14.
47. Milne, A., and P. Parboteeah. 2016. The business models and economics of peer-to-peer lending. In Research Report, European Credit Research Institute, No.17/May2016, 20.

48. Monzo Annual Report, 2017.

49. Noonan, L. 2017. UK's peer-to-peer lenders to be asked to reveal past defaults. Financial Times. https://www.ft.com/content/5160f 6de-7a97-11e7-9108-edda0bcbc928. 6 Aug 2017.

50. Peer2Peer Finance News. 2016. US P2P securitisation hits record high. 6 Oct 2016. Available at http://www.p2pfinancenews. co.uk/2016/10/06/us-p2p-securitisation/.

51. Peer2Peer Finance News. 2016. UK P2P set for securitisation boom. 5 Oct 2016. Available at http://www.p2pfinancenews. co.uk/2016/10/05/p2p-securitisation-moodys/.

52. Ricks. M. 2011. Regulating money creation after the crisis. 75 Harvard Business Law Review, 1: 104-106.

53. Shoffman, M. 2018. P2P securitisation boom still on the cards. Peer2Peer Finance News. 27 Mar 2018. Available at http://www. p2pfinancenews.co.uk/2018/03/27/p2p-securitisation/.

54. Starks, M. 2015. FCA Director of Competition, Disruptive innovation in financial markets at the OECD, 26 Oct 2015 (speech). Available at https://www.fca.org.uk/news/speeches/disruptive -innovation-financial-markets

55. Stevenson, D. 2018. FCA threatens clampdown on P2P lending. MoneyWeek, 05 Oct 2018.

56. Timperio, J., and M. Bear. 2014. The emergence of P2P loan securitizations. Law360, New York.

57. UK Finance. SME finance in the UK: past, present and future, December 2018, p. 11. Available at https://www.ukfinance.org. uk/system/files/UK-Finance-SME-Finance-in-UK-AW-web.pdf.

58. Williams, A. 2018. Fears as peer-to-peer loans start to sink. The Telegraph, https://www.telegraph.co.uk/investing/news/fears -peer-to-peer-loans-start-sink/. 19 Nov 2018.

59. World Economic Forum. 2016. The complex regulatory landscape for FinTech: An uncertain future for small and medium-sized enterprises lending. White Paper, 18-19.

60. Zetzsche, D., R. Buckley, D. Arner, J. Barberis. 2017. From Fintech to TechFin: The regulatory challenges of data-driven finance. EBI Working Paper Series, No. 6.

61. Zheng, Z., S. Xie, H. Dai, X. Chen, and H. Wang. 2017. An overview of Blockchain technology: architecture, consensus, and future trends. In IEEE 6th international congress on big data, $557-564$.

Publisher's Note Springer Nature remains neutral with regard to jurisdictional claims in published maps and institutional affiliations.

Vincenzo Bavoso is a Senior Lecturer in Commercial Law in the School of Law, University of Manchester. Before joining Manchester in 2014, he held academic posts at Durham University and Kingston University. He also holds visiting appointments at the Institute of Advanced Legal Studies, London, and at the China-EU School of Law, in Beijing. He has published widely in the areas of financial regulation, structured finance and corporate governance. 